\section{B A Institute of \\ YK Business Administration \\ 六下 \\ Karachi \\ Leadership and Ideas for Tomorrow}

Business Review

Volume 7 Issue 1 January-June 2012

$1-1-2012$

\title{
Financial reforms and corporate finance in emerging markets: An analysis of dividend policy among public listed firms in Pakistan
}

\author{
Mohammed Nishat \\ Institute of Business Administration, Karachi, Pakistan \\ Wali Ullah \\ Graduate School of Economics and Management, Tohoku University, Sendai, Japan
}

Follow this and additional works at: https://ir.iba.edu.pk/businessreview

Part of the Corporate Finance Commons, and the Finance and Financial Management Commons

\section{(c) (1)}

This work is licensed under a Creative Commons Attribution 4.0 International License.

\section{Recommended Citation}

Nishat, M., \& Ullah, W. (2012). Financial reforms and corporate finance in emerging markets: An analysis of dividend policy among public listed firms in Pakistan. Business Review, 7(1), 54-63. Retrieved from https://doi.org/10.54784/1990-6587.1301 


\title{
ARTICLE
}

\section{Financial Reforms and Corporate Finance in Emerging Markets: An Analysis of Dividend Policy among Public Listed Firms in Pakistan}

\author{
Mohammed Nishat \\ Institute of Business Administration, Karachi, Pakistan \\ Waliullah \\ Graduate School of Economics and Management, \\ Tohoku University, Sendai, Japan
}

\begin{abstract}
This paper analyzes the dividend behavior of 535 Pakistani listed companies during 1988 to 2005 using the Probit regression model. The findings validate the theoretical prediction for positive and significant impact of last year dividend on the current year dividend decision. More profitable and liquid firms have a higher probability to declare the dividends. Furthermore, firm size, ownership, equity and tax are positively related to the dividend declaration decision. The firms' dividend behavior differs significantly across industries. The secondary market development has a significant effect on dividend decision and financial liberalization has been associated with shift of firms from debt market to equity market.
\end{abstract}

\section{Introduction}

Dividend payout decision is a crucial component of corporate policy of the firms. Dividend declaration directly influences the investors' behavior, as a result ensuring the availability of capital through equity for productive investment opportunities. Since the publication of the irrelevance propositions of dividend policy of Miller and Modigliani (1961), several researchers (Rozeff, 1982; Rao and Sharma, 1983; Kumar and Kumar, 1984; Miller and Rock, 1985; Crutchley and Hansen, 1989; Smith and Watts, 1992; Jensen, Solberg, and Zorn, 1992; Moyer, Rao, and Tripathy, 1992; Akhigbe, Borde, and Madura, 1993; Hansen, Kumar, and Shome, 1994; Rao and Moyer, 1994; Nishat and Bilgrami, 1994; Collins, Saxena, and Wansley, 1996, Ferris, S., N. Sen, and H. Yui, 2006; Nishat and Waliullah, 2010) have empirically identified the factors which influence the dividend policies and practices of firms such as profit after tax, liquidity, change in equity holding, turnover of shares and size of the firm etc.

On the other hand the prospect of emerging markets, mainly driven by high growth potential, draws the attention of investors in search for investment opportunities. But financial markets in emerging economies are going through an early stage of financial developments, reforms and integration. Since 1990s many developing countries moved away from the restricted regime and introduced liberalization and financial reforms to allow the market greater role in the determination of interest rate and allocation of financial resources and firm dividend's behavior has evolved in response to these financial and economic reforms.

Through financial liberalization and opening of financial markets, many Asian countries have witnessed a huge inflow of capital through equity market, ensuring boom in 
the stock market. The bullish pattern in stock prices has resulted to attract many investors to participate after long financial repression and regulated monetary policies. In most of the developing countries where limited alternatives are available for investment, the magnitude of dividend is very important for these investors. It is established that the demand for the shares of those firms is higher who pay dividends and as a result the price of these shares increases (Nishat and Bilgrami, 1994).

In Pakistan, like many other emerging markets earlier in capital market's history, pricing decisions were heavily regulated and there were often fewer protections for investors. The bond and stock markets were constrained by a defective regulatory framework, lack of liquidity, limited arbitrage, high transaction costs, and poor response to various concessional and fiscal incentives. There have been restrictions for companies who could not offer shares above the book value (Mirza, 1993). These inefficiencies caused to re-examine the policies and search for alternative options.

Consequently, measures were taken to move towards more efficient and liberalized market. In addition, the reforms and institutional developments were initiated to remove the inefficiencies and market distortions to support the economic growth in the country (Nishat and Waliullah, 2010; Waliullah and Nishat, 2009). These restructuring reforms, starting in 1990, were directed to capital market strengthening included privatization of nationalized banks, corporate governance, improving asset quality, consumer financing, legal reforms, prudential regulations, credit rating and reduction in corporate taxation etc. Financial sector was restructured and opened up to competition. However, these institutional developments and financial reforms have increased the risk premia and genuine investors are concerned about firm's dividend behavior rather than risky capital gain (Waliullah and Nishat, 2010).

The existing literature describes and empirically determines the dividends policy in both developed and developing markets. In developed countries, generally, there exist efficient financial markets in which investors can diversify risks, which are supported by efficient legal system in which a broad range of property rights can be enforced. In contrast, in developing countries most financial markets are continuously going through the early stages of development process and the markets are relatively illiquid and heavily regulated (Booth, et al. 2001). In reviewing the dividend behavior in developing countries, the researchers have focused on the relationship between dividend payout ratio and its determinants, ignoring the institutional development and financial sector reforms. Specifically, the empirical work in this area is completely lacking the analysis of dividend behavior after reforms in the corporate sector.

In this study we evaluate the impact of opening financial market and integration along with other control variables on the dividend behavior in the context of an emerging economy. Therefore, the line of research pursued in this study is the inter-linkage of the relationships among corporate finance and financial liberalization. The basic objective of the study is to identify the determinants of dividend decision, the impact of financial liberalization on dividends decision and to test the relative potency of individual theories.

The remainder of the paper is organized as; in section 2 the theoretical frame is presented, followed by employed econometric methodology and data in section 3. Section 4 describes the empirical results and finally in section 5 the concluding remarks and policy implications are presented.

\section{Theoretical framework}

In order to test the hypothesis, the literature suggests that many factors influence the dividend payout choice of firms, such as firm size, profitability, growth opportunities, earning 
volatility, degree of operating leverage and liquidity. In this study we use last year 's dividend, profitability, surplus, net liquid assets, change in equity position, firm size, growth opportunities, leverage, tax, ownership of firm and reforms dummy as explanatory variables to assess their impact on the dividend behavior of the firm. Dependent variable is explicitly represented by a dummy variable, equal to one if the firm announces dividends in the particular year and zero otherwise.

The last year dividend per share has an imperative effect on the current year dividends declaration decision. It is believed that if the firm declares the dividends, the greater are the chances that the firm will also pay dividends in following years (Koutsoyiannnis, 1981). Therefore, the expected relationship between dividend declaration decision and last year dividend (DPS) is positive. Profitable firms have enough free cash-flows and paying dividends does not disturb their ongoing operation. In the same vein and according to the pecking order theory, profitable firms are internally financed and have lower interest payments commitments and thus could afford to pay higher dividends. In this study firm profitability is measured by return on assets (ROA) and is hypothesized to be positively correlated with dividend payments. Another influential determinant of dividends declaration decision is the firm surplus fund. The firms with higher allocation of friction of profit to retention (surplus) for other profitable investments and expansions will pay lower dividends to its shareholders. Therefore the expected relationship between dividends pay-out and surplus is negative. However last year surplus is expected to affect the dividends payment positively. The reason being that if surplus retained in investment is actualized may enhance the profit level of the firm, as a results the dividends may increase. Net liquid assets and cash-flow position is also an important determinant of dividend policy of the firm. Firms with poor liquidity position do not have enough free cash-flow to declare dividends. Alli et.al (1993) reveal that dividend payments depend more on cash flows, which reflect the firm's ability to pay dividends, than on the current earnings. Therefore, the expected relationship between net liquid assets (NLA) and dividends payout decision is positive.

The change in equity holdings explains the firm confidence in generating funds through equity. The increase in equity holdings will motivate the firms for higher dividends. Thus the expected relationship between equity holding measured by annual growth (CHE) of equity and dividends is positive. Another determinant of dividends decision is size of the firm. Size may be inversely related to the probability of bankruptcy (Ferri \& Jones, 1979; Titman \& Wessels, 1988; and Rajan \& Zingales, 1995). Larger firms tend to be more mature and thus have easier access to capital markets, which reduces their dependence on internally generated funding and allows for higher dividend payments. On the other hand, larger firms tend to be more diversified and have stable cash-flows, ensuring the dividends payments. We use the natural log of firm's total assets as a proxy for firm size (SIZE) and it is expected to be positively correlated with dividend payment.

It is hypothesized that growth oriented firms need funds to finance its expansion and other imbursement commitments. Accordingly earnings would be retained for profitable investment opportunities rather than dividends distribution. Since, firms with higher growth prospects pay out low dividends in order to preserve their growth. Therefore, it is expected that growth opportunities (GROW) measured as annual growth of sale will be negatively related with dividend payments. An important determinant of dividends decision is firm's leverage. Firm with high financial leverage tend to have low payout ratios to reduce the transaction and borrowing costs associated with external financing. Furthermore, leveraged firms do not have enough financial resources to pay dividends because their cash flows are already committed to make debt and interest payments and to avoid further borrowing due to unfavorable borrowing rate. Therefore the risk associated with high degrees of financial leverage may result in low dividend payments. Since, an inverse relationship between financial leverage (LEV), defined as the ratio of debt to equity, and dividends payments is expected. 
The tax-preference theory proposes that companies should retain their earning rather than distributing dividends because of the tax payment on dividends. The relative tax disadvantage of dividends makes retention more attractive and leads to a lower payout ratios. In order to examine any change in dividend payouts following the change in tax rate we use the ratio of tax provision to earnings before interest and tax expenses (TAX) as a proxy for tax disadvantages of dividends and anticipate a negative relationship between tax and dividends payment.

In Pakistan, the role of government in corporate financing decisions is pivotal given its dual roles as a major shareholder of state firms as well as the owner of all the major banks until recent privatization. After the 1970s nationalization of manufacturing sectors and banks, the state sector remains a formidable part of the national economy. Maintaining employment and social stability, instead of profit maximization in state owned enterprises (SOEs), has been the primary goal of the central government in Pakistan. To capture the diverse ownership mix in the data, in this study we employ a dummy variable (OWN) for identifying firm's ownership. The dummy variable, which takes the value of 1 if the firm is a public firm (government owned firms) and 0 otherwise (private owned firms) and is expected to have a negative relationship between public ownership and dividends payments.

Financial markets in Pakistan like many other developing countries have been under reforms process since 1990. Firm dividend's behavior has been evolved in response to financial and economic reforms and institutional developments. Therefore, in this study we have used a dummy variable in order to capture the impact of financial and economic reforms (REFORMS) on dividends declaration decision of firms. These reforms in Pakistan include change in debt-equity ratio, deregulation of financial sector, privatization and development of securities and stock markets. It should be observed that the reform in corporate sector has positive impact on dividend payment decision. The dummy variable is assigned value zero up to 1995 and one otherwise.

\section{Econometric model and data}

Based on above discussion the selected variables constitute the following general econometric model to be tested in order to determine the factors that may affect dividend policy. The general model to be estimated using the Probit specifications, for firm i in period t can be written as:

Figure 1: Econometric Model

$$
\begin{aligned}
& D_{u}=\beta_{0}+\beta_{1} D P S_{i, t-1}+\beta_{2} R O A_{\mathrm{u}}+\beta_{3} R O A_{i, t-1}+\beta_{4} S U R_{i t}+\beta_{6} N L A_{\mathrm{it}}+ \\
& \beta_{4} C H E_{i t}+\beta_{8} S_{Z} E_{i t}+\beta_{9} G R O W_{\mathrm{it}}+\beta_{10} L E V_{i t}+\beta_{4} S U R_{i t}+\beta_{11} T A X_{\mathrm{it}}+ \\
& \beta_{12} O W N_{\mathrm{it}}+\beta_{13} R E F O R M S_{\mathrm{i}}+\sum_{j=1}^{11} y_{j} D_{j}+E_{\mathrm{it}} \\
& \mathrm{i}=1, \ldots \ldots, 535 ; \quad \mathrm{j}=1,2 \ldots \ldots 11 ; \quad \mathrm{t}=1, \ldots \ldots .22
\end{aligned}
$$

where $D_{i t}$ is the dummy dependent variable is put equal to 1 if the firm pays dividends and 0 otherwise, $\mathrm{DPS}_{\mathrm{i}, \mathrm{t}-1}$ is the last year dividends, $\mathrm{ROA}_{\mathrm{it}}$ is the current year return on assets, 
$\mathrm{ROA}_{\mathrm{i}, \mathrm{t}-1}$ is the last year return on firm assets, $\mathrm{SUR}_{\mathrm{it}}$ is the current surplus, $\mathrm{SUR}_{\mathrm{i}, \mathrm{t}-1}$ is last year surplus, $\mathrm{NLA}_{i t}$ is net liquid assets of the firm, $\mathrm{CHE}_{\text {it }}$ is the change in firm equity position, SIZE $_{\text {it }}$ is firm size, GROW ${ }_{\text {it }}$ is the growth opportunities available to firm, LEV $_{\text {it }}$ is the leverage, $\mathrm{TAX}_{\mathrm{it}}$ is the corporate tax, $\mathrm{OWN}_{\mathrm{it}}$ is firm ownership and $\mathrm{Dj}$ are the eleven industries dummies to control for the industry effect. is the white noise error term.

In considering the dividend decision firms have only two options, either to pay dividends or not. This gives the dependent variable (dividends) a special feature that it can be specified in terms of two outcomes. It is either equal to zero or positive amount of dividend. Therefore, dependent variable takes the form of dummy variable. Simple linear regression estimation OLS is not appropriate method to analyze the dividend behavior, the implied model of the conditional mean places inappropriate restrictions on the residuals of the model. Furthermore, the fitted value of the dependent variable from a simple linear regression is not restricted to lie between zero and one. Instead, we adopt a Probit specification Chester Ittner Bliss $(1935,1938)$ that is designed to handle the specific requirements of binary dependent variable.

The Probit model is a popular specification of a generalized linear model. In particular, it is used for Binomial regression using the Probit link function. The response is a series of binomial results, the likelihood is often assumed to follow the binomial distribution.

$$
P(Y=1 \mid X=x)=\varnothing\left(x^{\prime} \beta\right)
$$

where $\mathrm{Y}$ is a binary outcome variable, $\mathrm{X}$ is a vector of regressors and $\mathrm{O}$ is the cumulative distribution function of the standard normal distribution. The parameters $\beta$ are typically estimated by maximum likelihood. The probit model can be generated by a simple latent variable model.

$$
Y^{*}=x^{\prime} \beta+e
$$

where, and suppose that $\mathrm{Y}$ is an indicator for whether the latent variable $\mathrm{Y}^{*}$ is positive:

$$
Y^{*}=1\left(\mathrm{Y}^{*}>0\right)=
$$$$
\left\{\begin{array}{l}
1 \text { if } Y^{*}>0 \\
0 \text { otherwise }
\end{array}\right.
$$

$$
P(Y=1 \mid X=x)=\varnothing\left(x^{\prime} ß\right)
$$

The function in equation 5 indicates the probability of success. The estimated coefficients using equation 1 measures the change in probability of paying dividends when certain explanatory variable changes holding other factors fixed.

$$
\triangle P(Y=1 \mid X=x)=\beta_{j} \Delta x_{j}
$$

The data employed in this study contains corporate financial data of 535 of public listed on Karachi Stock Exchange (KSE) for the period 1988 to 2005 (eighteen years). The data used in the analysis has been taken from various volumes of the "Balance Sheet Analysis of Joint Stock Companies Listed on The Karachi Stock Exchange". Table 1 presents the descriptive statistic of the data. 
https://ir.iba.edu.pk/businessreview/vol7/iss1/5

Table 1: Descriptive Statistic of Selected Variables

\begin{tabular}{|l|c|c|c|c|c|c|c|c|c|}
\hline & DPS & ROA & SUR & LIQ & CHE & SIZE & GROW & LEV & TAX \\
\hline Mean & 3.276 & 5.803 & 48.738 & 66.822 & 0.168 & 6.253 & 78.525 & 59.515 & 27.683 \\
\hline Median & 0.322 & 2.53 & 61.054 & 67.745 & 5.213 & 6.178 & 16.453 & 49.299 & 6.48 \\
\hline Maximum & 343.035 & 6839.6 & 62051.5 & 89.58 & 329.72 & 12.14 & 59 & 80.8 & 380.5 \\
\hline Minimum & 0 & 27.143 & 0 & 13.2 & 0 & 2.303 & 0 & 36.1 & -279.5 \\
\hline Std. Dev. & 15.353 & 128.925 & 273.669 & 59.116 & 127.133 & 1.618 & 644.312 & 55.591 & 34.022 \\
\hline Skewness & 11.479 & 29.047 & 5.943 & 25.238 & -9.609 & 0.051 & 82.778 & 12.551 & 14.439 \\
\hline Kurtosis & 167.292 & 134.409 & 186.352 & 80.275 & 901.223 & 5.095 & 680.486 & 25.008 & 37.935 \\
\hline Obs & 10271 & 10271 & 10271 & 10271 & 10271 & 10271 & 10271 & 10271 & 10271 \\
\hline
\end{tabular}

The number of companies included in the statistical analysis varies from year to year. There were 620 firms for which the data was available. However 85 companies were omitted because the available data was less than for 8 years, either due to their recent entry in the stock market or delisting from the stock market. Therefore, it is foreseeable that there might be unbalanced panel data for some firms. The analysis in this paper is thus based on the remaining 535 firms spread across the twelve industrial categories. (See appendix 1)

\section{Empirical results}

In order to ensure that our results are robust, several diagnostic tests were performed. In attempting to detect multicollinearity, we computed the correlation matrix for the independent variables. The estimated correlation values are small (much less than 0.5 ), presented in table 3 indicating that there is no multicollinearity between the variables. (See appendix 2)

Table 2 shows the results for the Probit regression model. The coefficients of most of the variables have the predicted sign and are statistically significant. The McFadden Rsquared for the model is 0.65 . The LR-statistic is 1039.343 , which is statistically significant at zero percent level of significance.

The results reveal that the last year dividend has a strong and statistically significant positive impact on the current dividends decision. Profitability (both current and last year) positively affects current year dividend payments. This provides strong support for the residual cash flow theory of dividends that firms with high cash flow pay high dividends and vice versa.

Table 2: Estimation of The Selected Probit Model

\begin{tabular}{|l|c|c|c|}
\hline Variables & Coefficient & t-Statistic & P-Value \\
\hline Intercept & -0.574 & -7.969 & 0.000 \\
\hline DPS $_{i, t-1}$ & 0.427 & 39.167 & 0.000 \\
\hline ROA $_{\text {it }}$ & 0.790 & 1.965 & 0.049 \\
\hline ROA $_{i,-1}$ & 0.125 & 1.692 & 0.090 \\
\hline SUR $_{\text {it }}$ & -0.012 & -0.723 & 0.469 \\
\hline SUR $_{i, t-1}$ & 0.023 & 1.038 & 0.299 \\
\hline NLA $_{\text {it }}$ & 0.637 & 1.902 & 0.057 \\
\hline
\end{tabular}


https://ir.iba.edu.pk/businessreview/vol7/iss1/5

DOI: https

Business Review - Volume 7 Number 1

January - June 2012

\begin{tabular}{|c|c|c|c|}
\hline Variables & Coefficient & t-Statistic & P-Value \\
\hline $\mathrm{CHE}_{\text {it }}$ & -0.001 & 1.776 & 0.075 \\
\hline SIZE $_{\text {it }}$ & 0.621 & 14.572 & 0.000 \\
\hline GROW it & -0.178 & -0.721 & 0.471 \\
\hline $\mathrm{LEV}_{\text {it }}$ & -0.296 & -2.181 & 0.013 \\
\hline $\mathrm{TAX}_{\mathrm{it}}$ & 0.381 & 2.952 & 0.003 \\
\hline $\mathrm{OWN}_{\mathrm{it}}$ & 0.317 & 3.246 & 0.001 \\
\hline REFORMS $_{\mathrm{t}}$ & 1.068 & 4.327 & 0.000 \\
\hline \multicolumn{4}{|l|}{ Industries Dummies } \\
\hline D1 (Textile) & -0.246 & -7.715 & 0.000 \\
\hline D2 (Chemicals) & 0.338 & 5.320 & 0.000 \\
\hline D3 (Engineering) & 0.108 & 1.989 & 0.046 \\
\hline D4 (Sugar) & 0.178 & 2.963 & 0.003 \\
\hline D5 (Paper \& Board) & 0.284 & 3.049 & 0.002 \\
\hline D6 (Cement) & 0.228 & 2.601 & 0.009 \\
\hline D7 (Fuel \& Energy) & -0.329 & -4.115 & 0.000 \\
\hline D8 (Trans. \& Comm) & -0.281 & -2.049 & 0.040 \\
\hline D9 (Tobacco) & 0.203 & 1.241 & 0.214 \\
\hline D10 (Jute) & -0.332 & -3.184 & 0.001 \\
\hline D11 (Vanaspati) & -0.414 & -5.093 & 0.000 \\
\hline \multicolumn{4}{|c|}{ Goodness of Fit Statistics } \\
\hline McFadden R-squared & 0.670 & Akaike info criterion & 1.139 \\
\hline LR statistic & $1139.343(0.000)$ & Schwarz criterion & 1.159 \\
\hline Log likelihood & -5729.290 & Hannan-Quinn criter. & 1.146 \\
\hline
\end{tabular}

The results support our assumptions, that current year surplus is negatively related and past year surplus is positively related to the dividend payout decisions, but both the coefficients are not statistically significant. Since firm retention policy does not play any role in dividends decision of the Pakistani listed firms. It shows that the retentions are not invested in the profitable investment opportunities and hence does not affect the corporate value. Besides, there is strong and statistically significant positive relationship between the net liquid assets and dividends policy as expected. Furthermore the results indicate that change in the equity position of the firms have a negative effect on the firm dividend decision, although the coefficient is extremely low in magnitude but statistically significant at $7 \%$ level of significance.

The results show that size has a positive effect on dividend yield consistent with the pecking order theory. This evidence suggests that larger companies have the opportunity to tap easily the financial markets by issuing stocks or bonds rather than retaining dividends. Besides, the absence of relationship between dividend policy and future growth opportunities obviously support the argument that the anticipation of future growth opportunities is not clearly relevant to dividends decision of listed firm in Pakistan. We find also that the financial leverage has highly significant negative impact on the dividend policy. The result confirms the corporate finance theory that risky firms pay out smaller dividends in order to lower its dependence on external financing. 
Corporate tax rate is highly significant and positively related to the firm dividends decision. The result suggest that companies in corporate sector distribute their income rather than retaining it and the listed firms in Pakistan are not much sensitive about the tax deductibility of interest expenses because of differential tax treatment and fiscal incentives in the various industries (Waliullah \& Nishat, 2009). There is positive and highly significant relation between dividend payouts and a firm's ownership, suggesting that state owned firms have higher motivation to pay dividends because it is easier for state owned firms to generate funds through debt financing and have less motivation to retained profit rather than distributing dividends. Financial reforms dummy has a positive and highly significant impact on dividends payout decision. This suggests that there is a substantial increase in dividend payment after the reforms in financial and corporate sector of 1990s. The secondary market development has a significant effect on dividend decision and financial liberalization has been associated with shift of firms from debt market to equity market. It suggests that firm's dividends policy is not only influenced by financial ratios such as size, profitability, tax advantage, recapitalization and financial distress costs (Mauer and Triantis, 1994), but also by exogenous financial sector development and reforms shocks. These exogenous shocks represent continuous events of deregulation in financial markets activities. The relative recent drive for financial reforms in most countries has been spurred by the belief that the existing financial structure was not adequate to promote and assist growth in real economy (Schiantarelli et al. 1994). Therefore many developing countries including Pakistan moved away from the restricted regime and introduced liberalization and financial reforms to allow the market greater role in the determination of interest rates and allocation of financial resources.

Finally, the results indicate that the dividend policy vary significantly across the various industries as all the industry dummies are statistically highly significant except the tobacco sector.

\section{Summary and concluding remarks}

In this study, factors that influence the dividend behavior of listed manufacturing companies in Pakistan are analyzed. The basic objective of the study is to identify the determinants of dividend decision and to test the relative potency of individual theories.

This study empirically examines the determinants of dividend decision of a pooled sample of 535 public listed non-financial companies from 1988 to 2005. In terms of methodology, the Probit econometric framework is used to establish the relationship between dividend decision and it determinants. The empirical findings validate the theoretical prediction for positive and significant impact of last year dividend per share on the current year dividend decision of the firm. This suggests that the firms reach their target dividend payout gradually. Profitability and liquidity firm are the strongest and most influential predictors of dividend behavior. More profitable and liquid firms have a higher probability to declare the dividends. Furthermore, the firms with higher equity pay higher dividends. Highly indebt risky firms tend to pay lesser dividends in order to lower its dependence on external financing.

Furthermore, firm size is positively related to dividends declaration, suggesting that larger companies have the opportunity to tap easily the financial markets by issuing stocks or bonds rather than retaining dividends. Tax and firm ownership are positively related to the dividend declaration decision. The results suggest that companies in corporate sector distribute their income rather than retaining it and the listed firms in Pakistan are not much sensitive about the tax deductibility of interest expenses because of differential tax treatment and fiscal incentives in the various industries. The results also suggest that government owned firms pay higher dividends rather than private firm. There is strong evidence indicating that dividend behavior differs significantly across industries, as the dummy variables are 
statistically significant. The results also suggest that the firms' surplus and growth opportunity does not have any significant impact on the dividend decision of the firms.

Financial reforms and liberalization is positively related to the dividends payout decision. This suggests that secondary market development has a significant effect on dividend decision and financial liberalization has been associated with shift of firms from debt market to equity market.

This study has significant policy implication. It shows firms dividend policy has been evolved in course of ongoing financial reforms and financial liberalization. The firms in our study sample who opted for debt as a source of financing have motivation to shift from debt market to equity market and catering their financing needs through capital market. As a policy implication, the capital market has to play its due role in generating long run capital so that the risk faced by a firm, associated with high debt financing, is minimized.

\section{References}

Akhigbe, A., Borde, S. F. and Madura, J. (1993). Dividend policy and signaling by insurance companies. The Journal of Risk and Insurance, 60, 413-428.

Alli, K. L., Khan, A. Q. and Gabriel G. R. (1993). Determinants of corporate dividend policy: A factorial analysis. The Financial Review, 28, 523-547.

Balance sheet analysis of joint stock companies listed on the Karachi Stock Exchange, various volumes (1988-2009), Statistics and DWH Department, State Bank of Bank of Pakistan.

Collins, M. C., Saxena, A. K. and Wansley, J. W. (1996). The role of insiders and dividend policy: A comparison of regulated and unregulated firms. Journal of Financial and Strategic Decisions, 9, 1-9.

Crutchley, C. and Hansen, R. (1989). A test of the agency theory of managerial ownership, corporate leverage, and corporate dividends. Financial Management, 18, 36-46.

Fama, E. F. and French, K. R. (2001). Disappearing dividends: changing firm characteristics or lower propensity to pay? Journal of Financial Economics, 60, 3-43.

Fama, E. F. and French, K. R. (2001). Testing trade-off and pecking order predictions about dividends and debt. The Review of Financial Studies, 15, 1-33.

Ferri, M. G. and Jones, W. H. (1979). Determinants of financial structure: A new approach. Journal of Finance, 34, 631-644.

Ferris, S., Sen, N. and Yui, H. (2006). God save the queen and her dividends: corporate payouts in the United Kingdom. Journal of Business, 70, 1149-1173.

Hansen, R. S., Kumar, R. and Shome, D. K. (1994). Dividend policy and corporate monitoring: evidence from the regulated electric utility industry. Financial Management, 23, 16-22.

Jensen, G. R., Solberg, D. P. and Zorn, T. S. (1992). Simultaneous determination of insider ownership, debt and dividend policies. Journal of Financial and Quantitative Analysis, 27, 274-263. 
Koutsoyiannis, A. (1981). Managerial job security and dividend policy of firms. Department of Economics Research series, University of Waterloo.

Miller, M. H. and Rock, K. (1985). Dividend policy under asymmetric information. Journal of Finance, 40, 1031-1051.

Moyer, R. C., Rao, R. and Tripathy, N. (1992). Dividend policy and regulatory risk: A test of the smith hypothesis. Journal of Economics and Business, 44, 127-134.

Nishat, M. and Bilgrami, N. (1994). Who pays dividend - An exploratory analysis of firms listed with karachi stock market. Saving and Development, 3, 335-343.

Rajan, R. and Zingales, L. (1995). What do we know about capital structure? Some evidence from international data", Journal of Finance, 50, 1421-1460.

Rao, R. and Moyer, R. C. (1994). Regulatory climate and electric utility capital structure decisions. The Financial Review, 29, 97-124.

Rozeff, M. S. (1982). Growth, beta and agency costs as determinants of dividend payout ratios. The Journal of Financial Research, 5, 249-259.

Smith C.W and Watts, R.L. (1992). The investment opportunity set and corporate financing, dividends and compensation policies. Journal of Financial Economics, 32, 263-292.

Titman, S. and Wessels, R. (1988). The determination of capital structure choice. Journal of Finance, 43, 1-19.

Waliullah and Nishat, M. (2009). Capital structure choice in an emerging market: evidence from listed firms in Pakistan. Conference proceedings, Pan-Pacific Business Conference XXVI, Shenzhen, China.

At every level in the course of knowledge and in the life of society, men seek to modify what they find. If such modification had not in the past knowledge and society would still be antediluvian. We live in a world which we must accept, but it is a world which we can also alter. The interplay of acceptance and alteration is discernible in all phases and stages of human civilization. While given things and institutions inevitably exact submission from us in many respects they also yields to the pressure of our ideas and ideals.

Knowledge and Society : A Philosophical Approach to Modern Civilization Department of Philosophy, University of California, Preface 